\title{
Urbanisation and Food Security: An Overview
}

\author{
Muhammad Uzair Azizan, Maryanti Mohd Raid, Khadijah Hussin* \\ Faculty of Geoinformation and Real Estate, Universiti Teknologi Malaysia, 81310 UTM Johor Bahru, Johor, Malaysia \\ *Corresponding author: khadijah@utm.my
}

\begin{abstract}
Urbanisation has given significant impact to various sectors, particularly in agriculture. Essentially, agricultural production activities depend heavily on land resources. At the same time, land is also needed as vital resources for the country development. Despite of the initiative of urbanism to better the country development process, it has raised concern among the land administrator regarding the status of the national's food security. Food security has been threatened by the needs of the physical development due to urbanisation. Therefore, this article attempts to study the impact of urbanisation on the agriculture sector and examined the role of urbanism to safeguard the land resources for food security purposes. It is hope that, this article will form an inclusive understanding regarding the idea of urbanism in pursuing the betterment of an economic progress without compromising the needs for the national food security.
\end{abstract}

Keywords: Urbanism, land resources, food security

(C) 2016 Penerbit UTM Press. All rights reserved

\subsection{INTRODUCTION}

Urbanisation has led to rapid economic development cause by the increasing number of population. Over the coming decades, the level of urbanisation is expected to increase in all regions, with Africa and Asia urbanised faster than other regions (Azizan and Hussin, 2015). In Malaysia, the growth of its population demonstrates a steady rate at $2.4 \%$ per annum with current population reached 30.3 million people (Department of Statistic Malaysia, 2015). With the rate of Foreign Direct Investment into this country increased tremendously from USD 10,074 million to USD 12,306 million, the need for construction sector especially for infrastructure development are overwhelming as to cater the demand of growing population (Maclaren, 2011).

Since land is a scarce and crucial resource, it has given a significant impact on agriculture sector. In many cases, agriculture land is being converted to some other development purposes or gives way to the urbanisation process. Essentially, agricultural activities depend on land resources for production. At the same time, land is also needed as vital resource for development. Since land conversion is driven by urbanisation and pressures agricultural land, presumably it will affect agriculture production and threaten the national food security. Therefore, this article attempts to study the impact of urbanisation on agriculture sector and examine the role of urbanism to safeguard land resource for food security.

\subsection{LITERATURE REVIEW}

In 2050, the demand for food is expected to increase greatly. One of the main factors that contribute to the increment of food demand is the growth of world population. The future food needs are projected based on population growth and it is found to be quite reliable. Malaysia is part of the Southeast Asia region and among the fastest developing countries in the world (Scott, 2001). In 2014, the total population has reached approximately 30.3 million compare to 29.8 million people in previous years. This number is expected to increase gradually and projected to reach 43 million people by the year 2050 (Department of Statistic Malaysia, 2014). Thus, this trend will indirectly increase food demand tremendously.

In order to fulfil the demand of the growing population, Malaysia has invested billions to maintain food supply. In 2013, Malaysia has remained as a net importer for food worth approximately RM15.6 billion for sugar, dairy products, cereal, vegetable and fruits as well as cocoa (MIDA, 2014). Moreover, UN's Food and Agriculture Organization (FAO) also estimated that the imports of rice in 2014 have increased to over 1.1 million tons which is more than the average level in the previous year (FAO, 2006).

In terms of the size of agriculture land allocation, the distribution of agriculture land in Malaysia throughout its 13 states are covered around 4.06 million hectares. Since 1980s, one of the major challenges experienced by Malaysia's agriculture sector is land accessibility, as agricultural land was been converted into other urban use particularly for industry, infrastructure and housing purposes (Bai, 2012). According to the statistic provided by the World Bank, agricultural land in Malaysia was last measured at $23.95 \%$ in 2009 (Rybczynski, 2005). However, according to the Second National Physical Plan, the size of agricultural areas has reduced over the years due to the pressure for urban development as illustrated in Table 1 below. More land, especially those adjacent to town, industries and housing areas are taken up for urban development. 
Table 1 Agricultural land use Peninsular Malaysia in Hectare (National Physical Plan 2, 2010).

\begin{tabular}{llcccc}
\hline & Crops & $\mathbf{1 9 9 7}$ & $\mathbf{2 0 0 2}$ & $\mathbf{2 0 0 6}$ & Difference \\
\hline 1. & Paddy & 410,000 & 405,800 & 331,036 & $-74,760$ \\
2. & Palm Oil & $2,174,500$ & $2,466,500$ & $2,816,513$ & 350,013 \\
3. Rubber & $1,759,100$ & $1,560,000$ & $1,284,912$ & $-275,088$ \\
4. Others & $1,632,400$ & $1,716,700$ & 808,099 & $-908,601$ \\
\multicolumn{2}{l}{ Total } & $\mathbf{5 , 9 7 6 , 0 0 0}$ & $\mathbf{6 , 1 4 9 , 0 0 0}$ & $\mathbf{5 , 2 4 0 , 5 6 0}$ & $\mathbf{- 9 0 8 , 4 4 1}$ \\
\hline
\end{tabular}

Many researchers are concerned about the urbanisation impacts on agriculture sector that consuming fertile land in the suburban areas around major cities. For instance, from 1990 to 2000, Malaysia has converted about 2 percent which is equivalent to 666,000 hectares of its agricultural land to non-agricultural use (World Bank, 2015). If this rate were to constantly increase, all agricultural land would be converted into urban use in 1500 years to come. Undoubtedly, it will affect the country's domestic food production and threatened the national food security.

Land conversion often had causes several problems such as insecurity of food production, the loss of cropland and some other issues. Thus, the spatial arrangement is vital to control and balance natural preservation within rapid physical development. However, land conversion is driven by many process of biophysical and socio economics (Van Doom and Bakker, 2007). Setiawan and Purwanto in Firman (1997) classified these drivers as internal and external drivers. The external drivers are found to include industrialization (Ho and Lin, 2004; Lichtenberg and Ding, 2008), urbanisation (Ho and Lin, 2004) infrastructure development (Ho and Lin, 2004; Lichtenberg and Ding, 2008; Nelson, 1990) and governmental policy. While, internal drivers are mainly include land productivity (Levia et al., 2000) as well as technology intensity. However, Hersperger and Burgi (2007) have divided the driving forces into five different groups. They are culture, nature, politic, economy and technology (Hersperger and Burgi, 2007).

Many countries have tried to preserve agricultural land from being converted to other uses (Lichtenberg and Ding, 2008). Others have acted passively or launched inappropriate plans to control the conversion. The complex nature of agricultural land conversion has made its driving forces, relationships and processes extremely important for different stakeholders such as scientists, agricultural land managers and policy makers to create appropriate strategies as practical measure to preserve agricultural lands from being converted to some other development purposes.

\subsection{THE URGENCY FOR FOOD SECURITY}

According to the definition by the World Food Summit, food security refers to the ability of people in physically and economically to access nutritious, safe and sufficient food at all times in order to meet their dietary needs and preferences through active and healthy lifestyles (FAO, 2006). This broad definition has become the main reference when discussing food security. Other author has also defined food security into small scope as an ability of a household to secure, either from its own production or through purchases, adequate food to meet the dietary needs of all its members (Maziya-Dixon et al., 2004).

It is important to understand that food security rely on food systems in order to provide stable, appropriate access, availability and use of food. However, it is hard to make a food system function accordingly as it will involve several factors (i.e. political, socioeconomic and biophysical), influencing other interests factors (i.e. governance, fiscal) across different range of levels (local or national) and scales (small or large). Achieving food security has emerged as one of the key development challenge for the less developed country in the 21 st century. But for a developed country, the challenges come in term of sustaining the food supply to achieve the demand of population. But curiously there is seems to be neglected.

Generally, around $60 \%$ or more of the total household expenditure, food holds the largest allocation in the budget of the urban poor. As addressed by some scholars, the main cause of food insecurity in most cases is food inaccessibility particularly due to lack of economic sources rather than food availability. However the availability of food in the future is expected to rely on the quantity of land supply, labour forces, capital investment, technology involved, water system, management skills of the production as well as the effectiveness of the food distribution system (Maclaren, 2011).

Today, due to global warming, the demand for bio fuels, unpredicted economic signals given by markets and governments to producers, has shown that the world is losing approximately one-third of the agriculture production (Maclaren, 2011). The growth rate of food production is expected to decline especially in poor countries where the growth of population keep increasing, if the government is unaware and not improving their food production system. But except, an extensive developments in production and its distribution are done through an application of the new technologies for an encouragement to improve economic signals then only will assists to increase the growth rate. It was believed that the effectiveness of the food demand in the future will be determined by the level of the income per capita and the size of the population. Even though the global population is projected to increase to 9 billion in 2050, it does not reflect that the simple linear relationship is parallel with the growth of the food production. In other words, there is a clear potential for food security to be improved in order to sustain the supply of demand in the equilibrium for the future needs.

\subsection{THE ROLE OF URBANISM TO SAFEGUARD LAND RESOURCE FOR FOOD SECURITY}

Urbanism is not a new philosophical framework in pursuing betterment to achieve the country's well-being. One of the main principles of the urbanism as somewhat encouraged by McHarg (1969) is the ability of the city to balance with the nature (McHarg, 1969). He explained 
that the principles promote the city to recognize sensitive zones, an ecosystem and the habitats that being threatened has to be protected through conservation, a density control, the land use planning and an open space design. Thus, the resource that was consumed during urbanisation process can be replaced through the natural replenishing cycles and creating an environmental stability.

According to Beatley (2000), through the implementation of urbanism idea, the city will likely to be characterised as an ecological friendly design city, able to reduce ecological footprint, create circular metabolism to establish network within the adjacent urban area to encourage walking and reduce driving, to provides population with their own food production and to promotes a healthy lifestyle through the liveable neighbourhoods. But according to Ma (2002), there are several other benefits that have been expected by urbanist in promoting their ideas (Ma, 2002) including the benefit to numerous stakeholders, including the residents, the businesses, the developers, the municipalities as well as the environment.

However, the question may arise as to whether the benefit mentioned above is good enough to show that the urbanist is really concerned with the issues of domestic food production? If they are only just focussing on the infrastructure and the facilities, it will not totally support boosting the sustainability of the regional economics. At the same time, the big question should also be answered whether the urbanist was aware of the attempt by other parties to fulfil the demand of the urban population for food by preserving the agriculture land that has been converted into other use and has threatened the production of the local food supply and so has also threatened the food security?.

It is not easy to restraint the process of urbanisation. Even though the idea of urbanism has promoted the city to be built in a sustainable manner, but the old city was formed thoughtlessly and was unprepared to overcome the impact of population growth and the problems associated with it. The scarcity and availability of land has become the major concern whereby both the developments of a physical and the agriculture requires and depends on the land resources to meet the demand of the population in terms of the food production and also the basic infrastructure.

The conflicting needs for land can be managed if the city is regulated and coordinated in a sustainable growth manner. However, managing urbanisation and development process is not just simply about formulation of strategies and programs, but also requires a decision making of the politician that has to be in parallel with the demand of the community (Porter, 2002). The planners and the policy maker must be aware of the urbanisation scale in order to steer and manage the related development process in a sustainable way (DFID, 2002).

In order to manage the urban growth efficiently, the planning instrument are necessary to make sure that development occurs on the exact location, in terms of its types, density and time. Zoning is believed to be among the effectives planning tools to manage an infill development through the mixed-development methods particularly within an urban boundary and as to encourage liveability. The standards as promoted by Beatley (2000) will also contribute to be a great potential and benefit to avoid the development poured beyond urban boundaries and encroaching on the countryside with undesirable physical and socio-economic impacts particularly on agriculture land.

Thus, the considerations of socio economics in terms of food security are vital in the planning process which directly touches on the food policy. Some of the scholars have thoughtlessly accepted this goal and others have also vigorously criticised the idea (Azizan and Hussin, 2015). As shown in Figure 1, the complexity of food policy consists of the production policy, the price and stability as well as the policy demand from the public. Any policy decisions regarding the demand and production of food will influence the global food prices and stability. Besides, it will also give an impact on the environment and the efforts to end poverty and hunger significantly. Therefore, food policy lies within the wider policy setting. In confronting the challenges of global food security, it has demanded the critical action in terms of the supply and demand, the governance to address the effect of any policy action regarding to environment, and lastly the needs of the world's poorest.

In this case, a policy remains as an effective tool to support the government approach in legal, management and decision-making aspects (McHarg, 1969). This mechanism is reasonably important to assist the municipalities to regulate the expansion of the city within its boundary, to coordinate the urban development, to manage land scarcity and to safeguard land resources from being converted into other urban uses. At the same time, it also assists the global food system in balancing the environmental in a sustainable manner. Obviously, the idea of urbanism is reasonably leading to favour sustainability and assist to safeguard scarce resources particularly land through promoting the city to manage the urban growth. Similarly, the idea also aims to encourage the social equity and the economic development, as the fundamentals pillars of a sustainable urbanisation.

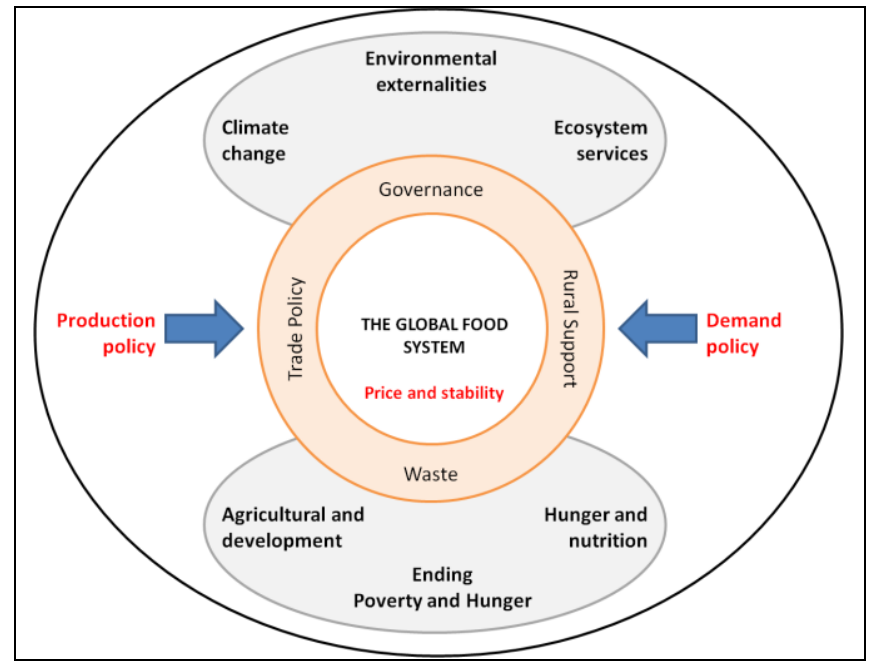

Figure 1: The Complexity of global food policy (Godfray and Garnett, 2014). 


\subsection{CONCLUSION}

It is obvious that the impact of urbanisation and population growth has caused changes in land use pattern. Unconsciously, agriculture land has to compete with any physical development that seems to be more economically significant to be placed on the limited urban land. Agriculture land often forced to gives way to infrastructure development to fulfil the demand of the growing population in terms of provision of basic needs especially housing. More and more land has been converted into urban use, threatening the agriculture land and food security.

From the discussion, it is clear that urbanisation has caused agriculture land to decrease in number prior to land conversion phenomenon. Thus, food production is declining and forces the country to import food and invest billions to maintain food supply for the growing populations. This delicate situation will indirectly impact on food security if practical measures fail to take place in the long run.

The idea of urbanism is basically to serve as antidote to prevent urban sprawl during the $19^{\text {th }}$ century. It encourages the management of the urban growth and favours the urban development towards sustainability. Similarly, the main principle of urbanism promotes a city to be balanced with the nature. Thus, managing urban growth in sustainable manner require the planning tools to effectively secure the land for the purpose of food production and physical development. Zoning, infill development, policy as such can prevent a city from encroaching any sensitive development area as well as assist a city to safeguard land resource particularly agriculture land for the purpose of food security.

Throughout the centuries urbanism has been about humans living in sustaining, and stimulating proximity. Interest in urbanism has surge in the past two decades. Urbanisms of many kinds have entered the urban lexicon, each staking out its own discriminating take on the urban realm. The urbanism of villages, neighbourhoods, towns, and cities drew people in as places of interaction, opportunity, and creativity. Going for urbanism is the key to community life, efficient public infrastructure, and preserving nature.

In the last few decades, the expansion of the city as the engine of economic development, technological transmission and cultural change has long been the subject of discussion among the scholars. The impact brought by urbanisation often seems to harm agriculture sector. For instance, urban-based enterprises depend on the production of the agricultural sector to ensure that other industry such as manufacturing also grew. It can simultaneously deny the assumption of some urbanist regarding to the insignificant of agricultural land in sub-urban or rural area instead of capital, labour and technology. It will also maintain the demand-supply curve of the raw material for agricultural products. So the key issue is within global decline in agriculture land area, does the growing and changing demands for food (and other agricultural products) that an increasingly urbanized population and economy brings can help to support agricultural sustainability and boost up awareness among urbanist and utopian on the issue of food security?.

In the context of Malaysia, the level of urbanization is likely to increase. If there is no intention from the authority to promote the idea of urbanism to preserve the potential land for food production, the population will struggle to live based on limited and insufficient food stock. Even the nation transformation programmes carry out from rural area into a liveable city with all of new spatial-economic policy, the issue of food security must not be forgotten and need to be addressed seriously as part of the national development agendas.

\section{Acknowledgment}

The authors are grateful to Land Administration and Development for the assistance in completing the paper.

\section{References}

Azizan, M. U., \& Hussin, K. (2015). Multiple Driving Forces Of Paddy Land Conversion: A Lesson From Malaysia's Rice Bowl State. Jurnal Teknologi, 78(1). Bai, X. (2012). Landscape Urbanisation And Food Security. The Scramble for Natural Resources: More food, less land, 60.

Beatley, T. (2000). Green Urbanism: Learning from European Cities. Island Press.

Bohl, C. (2000). New Urbanism And The City: Potential Applications And Implications For Distressed Inner-City Neighbourhoods. Housing Policy Debate Fannie Mae Foundation, 11(4), 791-797.

Bruegmann, R. (2005). Sprawl: A Compact History. Chicago: University of Chicago Press, 2005. ISBN 0-226-07691-1

Department of Statistic Malaysia (2015). Population by Age Group, Sex and Ethnic Group, Malaysia, 2000 - $2016 . \quad$ Retrieved at http://mysidc.statistics.gov.my/index.php?lang=en on 10th April 2015

DFID (Department for International Development). (2002). Sustainable Urbanisation: Achieving Agenda 21. London: UN-HABITAT and the UK Government Department for International Development (DFID).

FAO (2006). Policy Brief: Food Security. Issue 2, June 2006. Retrieved from http://www.fao.org/forestry/13128-0e6f36f27e0091055bec28ebe830f46b3.pdf.

Firman, T. (1997). Land Conversion And Urban Development In The Northern Region of West Java, Indonesia. Urban Studies, 34(7), 1027-1046

Fischer, G., Hizsnyik, E., Prieler, S., \& Wiberg, D. (2010). Scarcity and Abundance Of Land Resources: Competing Uses And The Shrinking Land Resource Base. SOLAW Background Thematic Report TR02. Rome, FAO.

Fulton, W. (1996). The New Urbanism: Hope or Hype for American Communities. Cambridge, MA: Lincoln Institute of Land Policy, USA.

Godfray, H. C. J., \& Garnett, T. (2014). Food Security And Sustainable Intensification. Phil. Trans. R. Soc. B, 369(1639), 20120273.

Gurin, D. (2003). Understanding Sprawl: A Citizen's Guide. The David Suzuki Foundation. Vancouver, Canada.

Han, S. S., \& He, C. X. (1999). Diminishing Farmland And Urban Development In China: 1993-1996. GeoJournal, 49(3), 257-267.

Hersperger, A. M., \& Bürgi, M. (2007). Driving Forces of Landscape Change in the Urbanizing Limmat Valley, Switzerland. In E. Koomen, J. Stillwell, A. Bakema \& H. J. Scholten (Eds.), Modelling Land-Use Change Progress and Applications, 90, 45-60. Dordrecht: Springer.

Ho, S. P., \& Lin, G. (2004). Converting Land to Nonagricultural Use in China's Coastal Provinces Evidence from Jiangsu. Modern China, $30(1)$, 81-112.

Knox, P. L. (1996). Globalization And Urban Change. Urban Geography, 17(1), 115-117

Kocieniewski, D. (2013). Major Companies Push the Limits of a Tax Break. The New York Times. Retrieved January 7, 2013

Levia, J., Delphis F, \& Page, D. R. (2000). The Use Of Cluster Analysis In Distinguishing Farmland Prone To Residential Development: A Case Study of Sterling, Massachusetts. Environmental Management, 25(5), 541-548.

Lichtenberg, E., \& Ding, C. (2008). Assessing Farmland Protection Policy in China. Land Use Policy, 25(1), 59-68.

Lin, G. C. S. (1994). Changing Theoretical Perspectives On Urbanization In Asian Developing Countries. Third World Planning Review, 16(1): 1-23.

Ma, B. (2002). New Urbanism and Urban Development in Contemporary China. Published thesis. School Architecture, Carleton University.

Maclaren, D. (2011) Exploring The Complexity Of Food Security. Retrieved at http://voice.unimelb.edu.au/volume-7/number-5/exploring-complexity-food-security on 7th April 2015

Malaysia's National Physical Plan 2, NPP (2010). Department of Town and Country Planning Peninsular Malaysia. 
Malaysia's National Urbanisation Policy, NUP (2006). Department of Town and Country Planning Peninsular Malaysia, Ministry of Housing and Local Government. ISBN 983-42643-2-1

Malaysian Investment Development Authority, MIDA. (2014). Retrieved from http://www.mida.gov.my/home/food-technology-and-sustainableresources/posts/?lg=EN

Maziya-Dixon, B., Akinyele, I.O., Oguntona, E.B., Nokoe, S., Sanusi, R.A., and Hariss, E.W., 2004. Nigeria Food Consumption and Nutrition Survey 2001-2003 Summary. International Institute of Tropical Agriculture (IITA), Ibadan, Nigeria, 1- 120.

McHarg, I. L. (1969). Design with nature. Garden City, N.Y: Published for the American Museum of Natural History, the Natural History Press.

Ministry of International Trade and Industry, MITI (2014). MITI Weekly Bulletin Vol. 280. Published on 4 March 2014. Malaysia.

Nelson, A. C. (1990). Economic Critique Of US Prime Farmland Preservation Policies: Towards State Policies That Influence Productive, Consumptive And Speculative Value Components Of The Farmland Market To Prevent Urban Sprawl And Foster Agricultural Production in the United States. Journal of Rural Studies, 6(2), 119-142. Phil. Trans. R. Soc. B 369: 20120273.

Porter, D. R. (2002). Making Smart Growth Work Washington, D.C.: Urban Land Institute.

Rybczynski, W. (2005). Suburban Despair: Is Urban Sprawl Really an American Menace. USA.

Salih, K. (1982). Urban Dilemmas in Southeast Asia. Singapore Journal Of Tropical Geography, 3(2), 147-161.

Scott, A. J. (ed.) (2001). Global City - Regions: Trends, Theory, Policy. Oxford: Oxford University Press.

Timmer, C. P., Falcon, W. P., Pearson, S. R., \& World Bank. Agriculture and Rural Development Dept. Economics and Policy Division. (1983). Food Policy Analysis, 1983, 1-301. Baltimore: Johns Hopkins University Press.

UNDESA (2014). World Urbanization Prospects, the 2014 Revision. New York: United Nations Department of Economic and Social Affairs, Population Division.

Van Doorn, A. M., \& Bakker, M. M. (2007). The Destination Of Arable Land In A Marginal Agricultural Landscape In South Portugal: An Exploration Of Land Use Change Determinants. Landscape Ecology, 22(7), 1073-1087

Wirth, L. (1938). Urbanism as a Way of Life. American Journal of Sociology, 1-24.

World Bank (2015). World Bank Indicator- Malaysia- Land Use. Retrieved from http://www.tradingeconomics.com/malaysia/agricultural-land-sq-km-wb-data.html 